\title{
HOUSEHOLD CUSTOMER SEGMENTATION BASED ON SATISFACTION USING THE CHAID METHOD
}

\author{
Fithriyyah Shalihati*), Raden Isma Anggraini*), Suhendi*), and Muchamad Bachtiar*) \\ *) School of Business, IPB University \\ Jl. Pajajaran, Bogor 16151, Indonesia
}

\begin{abstract}
In a nutshell, BUMD (Regional Government-Owned Enterprise) has two main roles, namely economic and social functions. The social function aims to meet the needs of all stakeholders, including the customer. Customer satisfaction is very important to implement this function, and one of the critical aspects is the service provided. In 2018, one of the BUMDs, namely PDAM faced a decreasing performance rating from 4.38 to 4.18 due to the decline in operational service. Therefore, it is very important to determine the customer satisfaction level. The objective of this research is to analyse the satisfaction level for products and services provided by PDAM in Bogor based on customer segmentation. It employs a descriptive analysis approach and the Chi-square Automatic Interaction Detector (CHAID) method. It selects 713 respondents from 148,755 household customers by using Cluster Stratified and Systematically Unproportionate Sampling (CSUS). The findings capture that the respondents are generally satisfied with the service provided except for complaint handling and dispute. Household customer segmentation is divided into 6 (six) clusters. The cluster that provides unsatisfied scores is mainly due to the quality of water, complaint handling and dispute, as well as tariffs and payments. Whereas, the cluster that provides a satisfying score is also due to the quality of water, complaint handling, and dispute resolution.
\end{abstract}

Keywords: BUMD, household, customer satisfaction, customer segmentation

\begin{abstract}
Abstrak: Secara singkat, BUMD (Badan Usaha Milik Daerah) memiliki dua peran utama, yaitu fungsi ekonomi dan fungsi sosial. Fungsi sosial bertujuan memenuhi kebutuhan semua pemangku kepentingan, termasuk pelanggan. Kepuasan pelanggan sangat penting untuk melaksanakan fungsi ini, dan salah satu aspek penting adalah layanan yang diberikan. Pada tahun 2018, salah satu BUMD yaitu PDAM mengalami penurunan peringkat kinerja dari 4,38 menjadi 4,18 karena penurunan layanan operasional. Oleh karena itu, sangat penting untuk menentukan tingkat kepuasan pelanggan. Penelitian ini bertujuan menganalisis tingkat kepuasan terhadap produk dan layanan yang diberikan oleh PDAM di Bogor berdasarkan segmentasi pelanggan. penelitian ini menggunakan pendekatan analisis deskriptif dan metode Chi-square Automatic Interaction Detector (CHAID). Ini memilih 713 responden dari 148.755 pelanggan rumah tangga dengan menggunakan Cluster Stratified dan Systematically Unproportionate Sampling (CSUS). Temuan menunjukkan bahwa responden umumnya puas dengan layanan yang diberikan kecuali untuk penanganan pengaduan dan sengketa. Segmentasi pelanggan rumah tangga dibagi menjadi 6 (enam) cluster. Klaster yang memberikan skor tidak puas ini terutama disebabkan oleh kualitas air, penanganan pengaduan dan sengketa, serta tarif dan pembayaran. Sedangkan klaster yang memberikan nilai memuaskan juga karena kualitas air, penanganan pengaduan, dan penyelesaian sengketa.
\end{abstract}

Kata kunci: BUMD, rumah tangga, kepuasan pelanggan, segmentasi pelanggan

\footnotetext{
${ }^{1}$ Corresponding author:

Email: oktyshalihati@gmail.com
} 


\section{INTRODUCTION}

Drinking water is a basic human need that must be met. The drinking water sector is so important that the provision of safe access to drinking water is one of the eight goals of the Millennium Development Goals (MDGs). The government has made safe access to drinking water one of the priority agendas according to the 2015-2019 National Medium-Term Plan (RPJMN), wherein 2019, it is expected that it is expected that it is expected that safe access to drinking water can reach $100 \%$ (universal access). Achieving 100\% access consists of $85 \%$ access to drinking water to meet the Minimum Service Standard (SPM) and 15\% access to drinking water to meet basic needs. Minimum Service Standards for drinking water according to Minister of Public Works Regulation No. 14 of 2010 is 60 liters/person / day, while meeting basic needs is 15 liters/person/day (Ministry of Public Works and Public Housing, 2017). Considering the importance of drinking water for meeting the community's needs, the management is carried out by government institutions in this case is a regional government-owned enterprise (BUMD). BUMD in general has two functions namely economic function and social function. The economic function is related to management by applying economic principles. While the social function is related to the ability to meet the community's needs in this case is the fulfilment of clean water (Bachtiar et al. 2020). One indicator in measuring BUMD has performed these two functions is from customer satisfaction based on an assessment of the services provided.

Service to customers is important for the intentions of public services determined by the quality of goods / services that customers want, so that quality assurance is a top priority for every company, which is currently used as a benchmark for the company's competitive advantage (Hadiyati, 2014; Khan et al. 2015).

The selection of PDAM TIRTA PAKUAN BOGOR is based on the results of the performance report of the Ministry of Public Works through the Agency for the Improvement of Drinking Water Supply System (BPPSPAM) every year to assess the performance of PDAM throughout Indonesia. Based on the report, it is known that in 2018 PDAM Bogor City experienced a decline in the value of performance from 4.38 to 4.188. The decline occurred in the operational sector, from 1.62 in 2017 to 1.42 in 2018 (BPPSPAM, 2019). The selection of household customers is because the majority of PDAM TIRTA PAKUAN BOGOR customers are 148,755 households or equivalent to 94.6\% of total customers (PDAM TIRTA PAKUAN BOGOR, 2019). More clearly about PDAM TIRTA PAKUAN BOGOR's performance assessment can be seen in the following Table 1.

Table 1. Assessment of PDAM TIRTA PAKUAN BOGOR Performance in 2018.

\begin{tabular}{lccc}
\hline \multirow{2}{*}{ Performance Assessment } & \multicolumn{3}{c}{ Assessment } \\
\cline { 2 - 4 } & 2016 & 2017 & 2018 \\
\hline Finance Sector & 1.09 & 1.03 & 1.03 \\
Service Sector & 1.10 & 1.10 & 1.10 \\
Operational Sector & 1.61 & 1.62 & 1.42 \\
Human Resources Sector & 0.59 & 0.63 & 0.63 \\
Total Performance & 4.39 & 4.38 & 4.18 \\
\hline
\end{tabular}

Based on Table 1, PDAM TIRTA PAKUAN BOGOR needs to improve performance, especially services in operational areas to improve customer satisfaction. Satisfaction is positively related to the company's results such as repeat purchases and an increase in the share of business that customers make with service providers (Hwang \& Zhao, 2010; Keiningham et al. 2003).

Service standards cover at least four things, namely 1). Standardized service procedures; for service providers and recipients; including complaints; 2). The settlement time determined from the time of submission of application until completion; 3). Service fees include the details specified in the service delivery process; 4). Service products are the results of services to be received in accordance with established conditions (Rahmayanty, 2010).

Many studies mention that customer satisfaction is influenced by service quality (Affandi et al. 2017; Pahlawan et al. 2019). This confirms the importance of service quality. The novelty in this study is to analyze customer segmentation based on their satisfaction with the services provided. The service used in this study consists of four service dimensions based on operational areas, namely water quality, tariffs and payments, Complaint Resolution and Disputes and Communication with Customers.

The purpose of this study is to analyze household customer satisfaction with PDAM TIRTA PAKUAN BOGOR service dimensions and identify household customer segmentation based on the level of customer 
satisfaction with PDAM TIRTA PAKUAN BOGOR services and provide recommendations to improve customer satisfaction.

\section{METHODS}

This research was conducted in the Bogor City from November to December 2019. Types of data used are primary and secondary data. Primary data were obtained from respondents who were PDAM TIRTA PAKUAN BOGOR household customers using a questionnaire instrument, while secondary data were obtained from various relevant sources such as the annual PDAM TIRTA PAKUAN BOGOR report, journals related to customer satisfaction and books and other relevant sources.

Method of determining and selecting samples using Morgan Krisje with an error rate of $4 \%$ from a population of 148,755 households, a minimum number of samples was obtained 598. The number of respondents surveyed in this study were, 718 respondents consisting of eight households using the Cluster Stratified and Systematically Un-proportionate Sampling (CSUS) technique.

Data analysis in this study uses a quantitative approach. The quantitative analysis used is descriptive statistical analysis and CHAID (Chi-square Automatic Interaction Detector). This descriptive analysis includes several things, namely frequency distribution, measurement of central tendency, and measurement of variability (Affandi et al. 2017; Pahlawan et al. 2019). Descriptive statistical analysis is used to describe a situation or problem so that it is more easily understood. Namely, the frequency distribution and measurement of central tendencies to identify customer satisfaction level on a scale of 1 to 4 . The satisfaction is obtained from PDAM Tirta Pakuan product services' performance evaluation divided into four dimensions, namely: 1). water quality; 2). rates and payments, which include the following elements: 3). Settlement of Complaints and Disputes, which include elements of: and 4). Communication with Customers (Anggraini et al. 2020).

CHAID (Chi-square Automatic Interaction Detector) analysis used to find the basic relationship between changes. The CHAID analysis predicts a predictive model or tree to determine how the best variables combine to explain the results in the dependent variable used.

The use of CHAID analysis can explain the nature of the problem more than traditional analysis (Díaz-Pérez \& Bethencourt-Cejas, 2016). The CHAID analysis produces a "dendrogram", which illustrates a grouping of people based on the response variable's structured relationship with a significant explanatory indicator at a significant level $\alpha=0.05$. The indicators used consist of 9 indicators of customer characteristics and 4 indicators of service dimensions. The nine indicators of customer characteristics analysed are: [1] Group, Zone, [2] Notification of disturbance, [3] Gender, [4] Education, [5] Income, [6] Length of subscription, [7] Form of subscription, [8] Type of connection, and [9] District. The service dimension indicators analysed are [1] Water Quality, [2] Rates and Payment, [3] Complaints and Disputes Settlement and [4] Communication with Customers. The research framework can be seen in Figure 1.

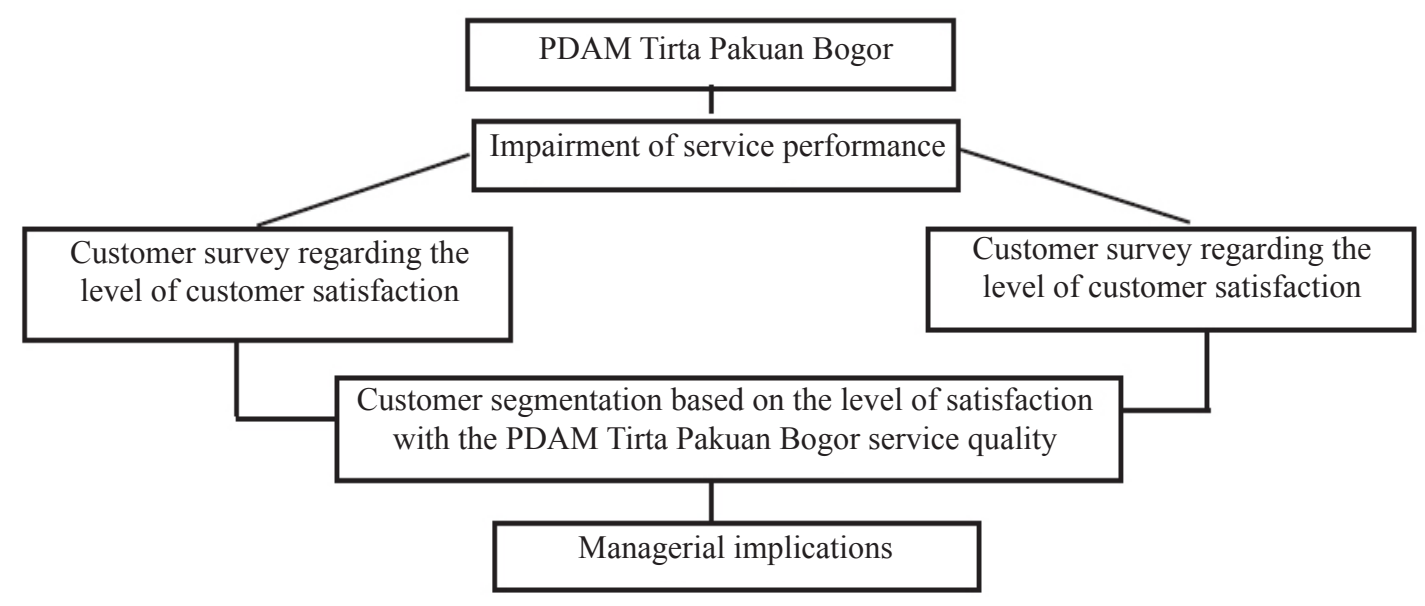

Figure 1. The research framework 


\section{RESULTS}

\section{PDAM TIRTA PAKUAN BOGOR Service Dimension Satisfaction}

The assessment of service dimensions for PDAM household customers, generally known that household customers are satisfied with PDAM TIRTA PAKUAN BOGOR services, this is indicated by an average value of 3.03 from a scale of 4 . This satisfaction is in accordance with the performance appraisal of BPPSPAM which considers that PDAM TIRTA PAKUAN BOGOR is an SPAM organizer that is in the healthy category (BPPSPAM, 2019, p. 43).

If viewed based on the dimensions, it is known that only the settlement of complaints which value is less than 3 or included in the category of not good. This shows PDAM TIRTA PAKUAN BOGOR needs to increase the dimensions of complaint and dispute resolution by improving services such as improving service officers' ability, call centre officers, social media and website administrators, compensation and fairness in getting services. When viewed based on the standard deviation values, it is known that the dimension of communication with customers has the highest standard deviation values, this shows that the assessment of household customers varies considerably due to the services received. Therefore PDAM Tirta Pakuan needs to pay attention to employees, especially in providing information on service interruptions so that PDAM TIRTA PAKUAN BOGOR household customers do not experience information gaps. Customer relations are important for PDAM. This is demonstrated by the creation of a customer service module which is a collaboration of the Directorate of Drinking Water Supply System Development (Dit. PSPAM), in collaboration with JICA Expert Team (JET) since 2015 (Directorate of Drinking Water Supply System Development, 2018). Clearer about PDAM Tirta Pakuan Customer Satisfaction Analysis based on Service Dimensions

\section{PDAM TIRTA PAKUAN BOGOR Household Customer Segmentation Based on Satisfaction}

Based on the CHAID analysis results, it is known from the 11 indicators analysed that only 4 indicators are explanatory, namely District, Water Quality, Tariffs and Payments, Complaint Resolution and Disputes and Communication with Customers. The four explanatory indicators can be classified into 6 groups, as presented in Table 4.

Table 2. Descriptive analysis of household customer satisfaction ratings based on service dimensions

\begin{tabular}{lll}
\hline Service Dimensions & Average & Stdev \\
\hline Water Quality & 3,03 & 0,30 \\
Rates and Payments & 3,10 & 0,30 \\
Complaints and Disputes Settlement & 2,99 & 0,44 \\
Communication with Customers & 3,01 & 0,52 \\
Average & 3,03 & \\
\hline
\end{tabular}

Table 3. Classification Based on CHAID Tree Diagrams

\begin{tabular}{|c|c|c|}
\hline Classification & Node & Description \\
\hline 1 & 1,3 and 7 & $\begin{array}{l}\text { The assessment of the dimensions of water quality, quantity and continuity, settlement of } \\
\text { complaints and disputes as well as inadequate tariffs and payments }\end{array}$ \\
\hline 2 & 1,3 and 8 & $\begin{array}{l}\text { The assessment of the dimensions of quality, quantity and continuity of water, the } \\
\text { resolution of complaints and disputes are not good, but the rates and payments are } \\
\text { considered to be good }\end{array}$ \\
\hline 3 & 1 , and 4 & $\begin{array}{l}\text { The assessment of the dimensions of water quality, quantity and continuity are not good } \\
\text { but the complaints and disputes are well resolved }\end{array}$ \\
\hline 4 & 2,5 and 9 & $\begin{array}{l}\text { The assessment of the dimensions of water quality, quantity and continuity were assessed } \\
\text { as good, but complaints and disputes were not well settled in Bogor Tengah and Bogor } \\
\text { Timur. }\end{array}$ \\
\hline 5 & 2,5 and 10 & $\begin{array}{l}\text { The assessment of the dimensions of quality, quantity and continuity of water are } \\
\text { considered to be good, but the resolution of complaints and disputes is not good which is } \\
\text { domiciled in Tanah Sereal, Bogor Selatan, Bogor Utara, Bogor Barat and Bogor Regency }\end{array}$ \\
\hline 6 & 2 and 6 & $\begin{array}{l}\text { The assessment of the dimensions of water quality, quantity and continuity are not good } \\
\text { and the complaints and disputes are judged to be good }\end{array}$ \\
\hline
\end{tabular}


This prediction's accuracy is then used to test the output risk of the allegations made or the output risk to "test the goodness of the model". The result of risk estimation shows that the estimated value is 0.101 , which means the risk of error in estimating is estimated at $10.1 \%$. This means that the model will have an error rate in predicting or have an error rate classifying the community by $10.1 \%$ as a whole.

The accuracy of this prediction is categorized as Good, this is indicated by the accuracy value reaching 97 percent for PDAM TIRTA PAKUAN BOGOR household customers who rate satisfied, while those assessing dissatisfied predictions of accuracy are 80.5 percent (Table 5).

Based on the classification in Table 3 then in Table 6 the percentage distribution of each classification or characteristic is presented. Based on Table 6, an illustration is obtained that characteristics 1 and 2 are groups that "value less satisfied", while people with classifications of groups 3, 4 and 5 are included in the "satisfied" category. In this regard, it can be said that the variables that influence the satisfaction and dissatisfaction of household customers are the dimensions of water quality service, complaint and dispute resolution, tariff and payment dimensions and sub-districts.

Based on Figure 2, it is known that the possibility of PDAM TIRTA PAKUAN BOGOR, household customers will be dissatisfied if the water quality, complaints and disputes settlement and tariff and payment are considered not good by $98.1 \%$, if the assessment of water quality dimensions, complaints and disputes settlement is not good, however, tariffs and payments are considered good then the possibility of dissatisfaction decreases to $84.9 \%$. This shows that increasing the dimensions of water quality, settlement of complaints and disputes and tariffs and payments are dimensions of service that must be prioritized. If the service dimensions of water quality and complaint handling are considered good then it is likely that household customers will be satisfied by $99.6 \%$. This is in accordance with Bachtiar et.al research which states that to improve customer satisfaction requires good product quality (water) by paying attention to water supply and distribution, as well as maintaining the quantity and quality (purity) of water (Bachtiar et al. 2020). If seen from the satisfaction of household users based on sub-districts, the thing to note is that PDAM TIRTA PAKUAN BOGOR household users in Tanah Sereal, South Bogor, North Bogor, West Bogor and Bogor Districts have a greater dissatisfaction tendency compared to Central and East Bogor subdistricts. Therefore, it is important to consider the dimensions of water quality and the dimensions of resolving complaints and disputes for household users who live in Tanah Sereal sub-districts, South Bogor, North Bogor, West Bogor and Bogor Regency.

\section{Managerial Implications}

Some things that need attention from PDAM TIRTA PAKUAN BOGOR management are as follows: Improve service dimensions for water quality, settlement of complaints and disputes as well as tariffs and payments. Improving water quality can be done by periodically checking the water supply in the field and improving the water supply and distribution system that allows anticipating the impact of natural factors (seasonal). Improving the quality of complaints and dispute resolution can be done by increasing the response in handling customer complaints and providing the solutive input, increasing the ability of Service officers, Call Centre officers, social media and website administrators, fairness in getting services and arranging compensation systems for service interruptions for customers according to with customer expectations. Improve consistency in communication with customers to reduce the variety of ratings from household users.

Table 4. Output risk

\begin{tabular}{ll}
\hline & Risk \\
\hline Estimate & Std. Error \\
.101 & .011 \\
\hline
\end{tabular}

Growing Method: CHAID

Dependent Variable: Satisfaction

Table 5. Classification according to satisfaction

\begin{tabular}{lccc}
\hline \multicolumn{4}{c}{ Classification } \\
\hline Observed & \multicolumn{3}{c}{ Predicted } \\
\cline { 2 - 4 } & Dis-satisfy & Satisfy & Percent Correct \\
\hline Dis-satisfy & 248 & 60 & $80.5 \%$ \\
Satisfy & 12 & 393 & $97.0 \%$ \\
Overall & $36.5 \%$ & $63.5 \%$ & $89.9 \%$ \\
Percentage & & &
\end{tabular}

Growing Method: CHAID

Dependent Variable: Satisfaction 


\begin{tabular}{lcc}
\hline & Assessment \\
\hline & Satisfy & Dis-satisfy \\
\hline $\begin{array}{l}\text { The assessment of the dimensions of water quality. settlement of complaints and disputes as } \\
\text { well as tariffs and payments are not good }\end{array}$ & 1.9 & 98.1 \\
$\begin{array}{l}\text { The assessment of the dimensions of water quality, complaints and disputes are not good, but } \\
\text { the tariff and payment are considered to be good }\end{array}$ & 15.1 & 84.9 \\
$\begin{array}{l}\text { The assessment of the dimensions of water quality, quantity and continuity are not good but } \\
\text { the complaints and disputes are well resolved }\end{array}$ & 56.4 & 43.6 \\
$\begin{array}{l}\text { The assessment of the dimensions of water quality, quantity and continuity are assessed as } \\
\text { good, but complaints and disputes are not well settled domiciled in Bogor Tengah and Bogor } \\
\text { Timur }\end{array}$ & 96.1 \\
$\begin{array}{l}\text { The assessment of the dimensions of quality, quantity and continuity of water are considered } \\
\text { to be good, but the resolution of complaints and disputes is not good which is domiciled in }\end{array}$ & 67.1 \\
$\begin{array}{l}\text { Tanah Sereal, Bogor Selatan, Bogor Utara, Bogor Barat and Bogor Regency } \\
\text { The assessment of the dimensions of water quality, quantity and continuity are not good and } \\
\text { the complaints and disputes are judged to be good }\end{array}$ & 99.6 & 32.9 \\
\hline
\end{tabular}

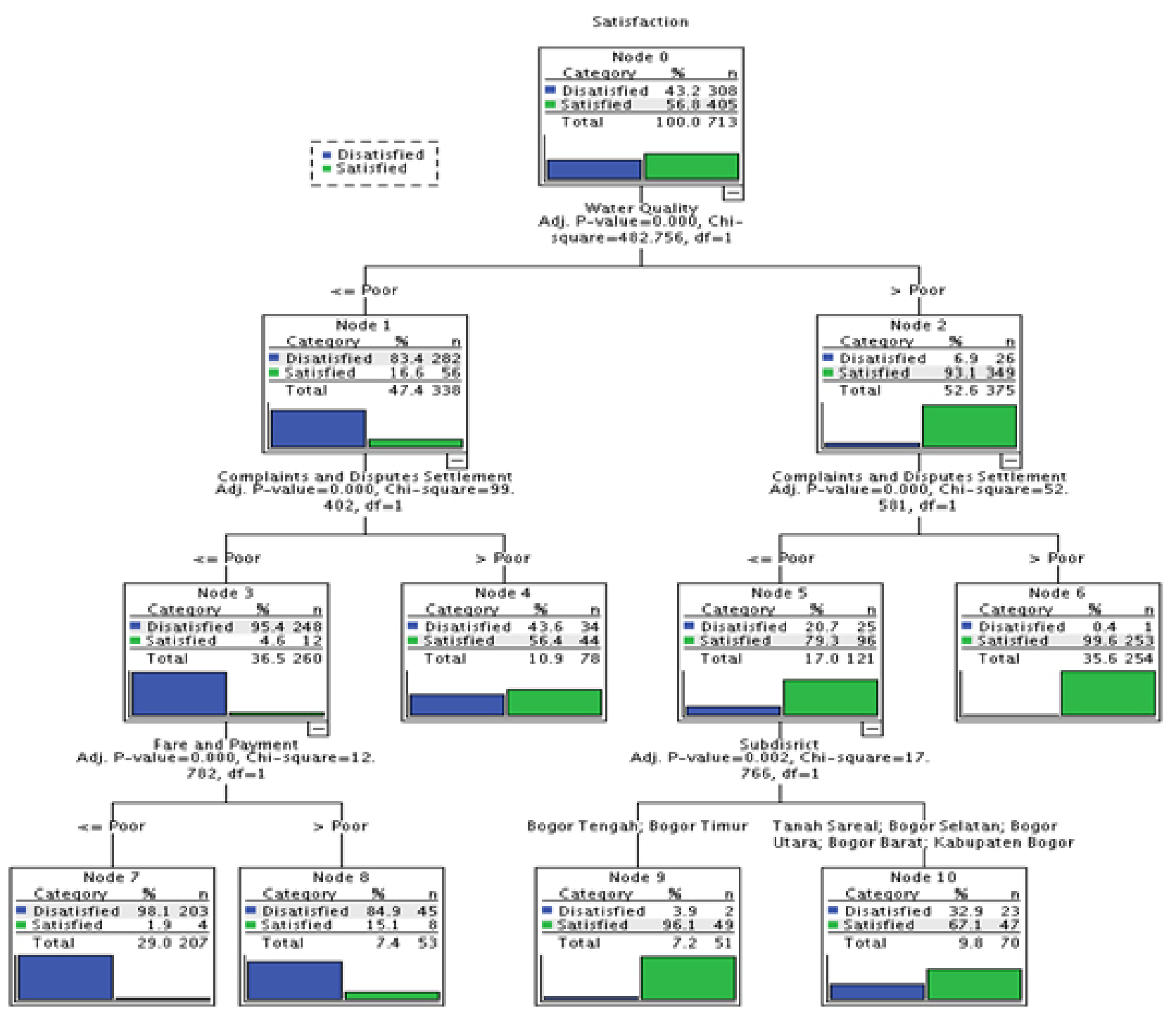

Figure 2. CHAID analysis tree diagram based on customer satisfaction 


\section{CONCLUSIONS AND RECOMMENDATIONS}

\section{Conclusions}

This study's results indicate that the assessment of the service dimensions of PDAM TIRTA PAKUAN BOGOR household customers is generally considered to be satisfied, only one dimension is considered to be lacking, namely the resolution of complaints and disputes. Household customer segmentation based on satisfaction can be divided into six groups. The groups predicted to be less satisfied are those who judge poorly on the dimensions of water quality, settlement of complaints and disputes as well as tariffs and payments. Household customer groups that assess satisfaction have characteristics that feel good service for the dimensions of water quality and resolution of complaints and disputes.

\section{Recommendations}

This research is only limited to PDAM TIRTA PAKUAN BOGOR customers from household groups. This research has not identified customers from other groups such as industry, commerce, government and social institutions. Therefore, more comprehensive research is needed by taking representative samples from all PDAM TIRTA PAKUAN BOGOR customers. New research can also be done with satisfaction analysis using the Taguchi's Signal-to-Noise Ratio approach as a new method of measuring service quality to improve customer satisfaction.

\section{REFERENCES}

Affandi H, Zaki M, Azmeri. 2017. Pengaruh kualitas pelayanan terhadap kepuasan pelanggan pada Perusahaan Daerah Air Minum (PDAM) Tirta Mon Pase Kabupaten Aceh Utara. Jurnal Teknik Sipil 6(3): 297-308.

Anggraini RI, Shalihati F, Bachtiar M, suhendi. 2020. Communication strategy in handling customer complaints in PDAM TIRTAPAKUAN BOGOR. Business Review and Case Studies 1(1): 32-32. https://doi.org/10.17358/brcs.1.1.32

Bachtiar M, Anggraini RI, Shalihati F. 2020. Using the Important performance analysis to improve product and service attribute performance in regional-owned enterprise. Business Review and Case Studies 1(1): 14-14. https://doi. org/10.17358/brcs.1.1.14

BPPSPAM. 2019. Buku Kinerja BUMD Penyelenggara SPAM 2019. Jakarta: Kementerian Pekerjaan Umum dan Perumahan Rakyat.

Díaz-Pérez FM, Bethencourt-Cejas M. 2016. CHAID algorithm as an appropriate analytical method for tourism market segmentation. Journal of Destination Marketing \& Management 5(3): 275-282. https://doi.org/10.1016/j. jdmm.2016.01.006

Direktorat Pengembangan Sistem Penyediaan Air Minum. 2018. Modul Pelayanan Pelanggan Tahun 2018. Jakarta: Kementerian Pekerjaan Umum dan Perumahan Rakyat dan JICA.

Hadiyati E. 2014. Impact of service quality on customer satisfaction in Indonesian public sector organizations. International Journal of Management Sciences and Business Research (IJMSBR) 3(12): 92-99.

Hwang J, Zhao J. 2010. Factors influencing customer satisfaction or dissatisfaction in the restaurant business using answer tree methodology. Journal of Quality Assurance in Hospitality \& Tourism 11(2): 93-110. https://doi. org/10.1080/15280081003800355.

Keiningham TL, Perkins-munn T, Evans H. 2003. The impact of customer satisfaction on share-ofwallet in a business-to-business environment. Journal of Service Research 6(1): 37-50. https:// doi.org/10.1177/1094670503254275.

Kementerian Pekerjaan Umum dan Perumahan Rakyat. 2017. Rencana Strategis BPPSPAM TAHUN 2018-20122. Jakarta: Kementerian Pekerjaan Umum dan Perumahan Rakyat.

Khan MB, Batool I, Hussain S. 2015. Customer satisfaction at public sector: a case study of Pakistan Housing Authority. Pakistan Journal of Social Sciences (PJSS) 35(2): 1037-1050.

Pahlawan MR, Laba AR, Pakki E, Hardiyono, Nurlia. 2019. Pengaruh kualitas produk dan kualitas pelayanan terhadap peningkatan kepuasan dan loyalitas pelanggan Perusahaan Daerah Air Minum (PDAM) Kota Makasar. Journal of Business Administration 3(2): 228-244.

PDAM TIRTA PAKUAN BOGOR. 2019. Laporan Akhir Survey Kepuasan Pelanggan (SKP) PDAM TIRTA PAKUAN BOGOR Tahun 2018. Bogor: PDAM.

Rahmayanty N. 2010. Manajemen Pelayanan Prima (cetakan pertama). Tangerang: Graha Ilmu. 